\title{
Isolation and recovery of glycomacropeptide from milk whey by means of thermal treatment
}

\author{
Isolamento e recuperação do glycomacropeptido do soro de leite mediante tratamento térmico
}

Evelin ROJAS ${ }^{1 \star}$, Gabriel TORRES ${ }^{1}$

\begin{abstract}
During enzymatic process of cheese manufacturing, rennin cleaves $\kappa$-casein releasing two fractions: para- $\kappa$-casein and glycomacropeptide (GMP), which remains soluble in milk whey. GMP is a peptide with structural particularities such as chain carbohydrates linked to specific threonine residues, to which a great variety of biological activities is attributed. Worldwide cheese production has increased generating high volumes of milk whey that could be efficiently used as an alternative source of high quality peptide or protein in foodstuff formulations. In order to evaluate isolation and recovery on whey GMP by means of thermal treatment $\left(90^{\circ} \mathrm{C}\right), 18$ samples $(2 \mathrm{~L}$ each) of sweet whey, resuspended commercial whey (positive control) and acid whey (negative control) were processed. Indirect presence of GMP was verified using chemical tests and PAGE-SDS $15 \%$. At $90^{\circ} \mathrm{C}$ treated sweet whey, 14, 20 and $41 \mathrm{kDa}$ bands were observed. These bands may correspond to olygomers of GMP. Peptide recovery showed an average of $1.5 \mathrm{~g} / \mathrm{L}$ (34.08\%). The results indicate that industrial scale GMP production is feasible; however, further research must be carried out for the biological and nutritional evaluation of GMP's incorporation to foodstuff as a supplement.

Keywords: glycomacropeptide; PAGE-SDS; whey; GMP isolation.
\end{abstract}

\section{Resumo}

No processo enzimático da elaboração do queijo, a renina hidrolisa a $\kappa$-caseína gerando duas frações: a para- $\kappa$-caseína e o glycomacropeptido (GMP) que se faz solúvel no lactossoro. O GMP é um péptido com particularidades estruturais como a presença de carbo-hidratos colados a resíduos específicos da treonina, ao qual se atribui uma enorme variedade de atividades biológicas. A produção mundial de queijo aumentou, gerando um grande volume de soro de leite que pode ser utilizado de forma eficiente como fonte alternativa de peptídeo ou proteína de alta qualidade, na formulação de alimentos. Para fazer uma avaliação do isolamento e recuperação do GMP mediante tratamento térmico do lactossoro a $90^{\circ} \mathrm{C}$, processar-se-ão 18 amostras ( $2 \mathrm{~L}$ cada uma) de soro doce, soro comercial ressuspendido (controle positivo) e soro ácido (controle negativo). Verificou-se de maneira indireta, mediante provas químicas e PAGE-SDS 15\%, a presença de GMP nas preparações. Foram observadas bandas de 14; 20; e $41 \mathrm{kDa}$ no soro doce tratado a $90^{\circ} \mathrm{C}$. Essas bandas provavelmente correspondam a oligómeros do GMP. A recuperação do péptido resultou na média $1,50 \mathrm{~g} / \mathrm{L}$ (34,08\%). Os resultados indicam que a produção em escala industrial do GMP é viável, no entanto uma investigação deve ser feita para avaliação biológica e nutricional da incorporação do GMP em alimentos como um suplemento. Palavras-chave: glycomacropeptido; PAGE-SDS; soro; isolamento do GMP.

\section{Introduction}

During cheese manufacturing process, rennin hydrolyzes $\kappa$-casein in the Phe105- Met106 bond generating two fractions: para-k-casein with amino acid residues from 1-105, and glycomacropeptide (GMP) from 106-169, which remains soluble in milk whey. The product from casein enzymatic clotting is known as sweet whey (ABD EL-SALAM; EL-SHIBINI; BUCHHEIM, 1996; BRODY, 2000).

GMP is a C-terminal hydrophilic casein-peptide formed by 64 amino acid residues which presents up to four carbohydrate chains (sialic acid-galactose-N-acetyl galactosamine) bonded to threonine residues in six different positions $(121 ; 131 ; 133$; $136 ; 142$, and 165). Ramified chain amino acids prevail in its structure; nevertheless there is absence of aromatic amino acids (phenylalanine, tryptophan, and tyrosine). Depending on the $\kappa$-casein variant that forms GMP, it may contain phosphorus up to $0.4 \%$ and present an approximate molecular mass between
6,8 and $8,0 \mathrm{kDa}$ in its monomeric state. Recent research established GMP concentrations of 1.2-1.5 g/L in whey from cheese manufacturing, which accounts for between $10-25 \%$ of whey protein (CHOW; HARPER, 2001).

In the last decade, interest in whey proteins and peptides study has increased, among them GMP which exhibits biological, techno-functional, and nutritional properties that leads to health benefits (MARSHALL, 1991, 2004; BRODY, 2000; BARÓ et al., 2001; DOULTANI; TURHAN; ETZEL, 2003; ETZEL, 2004; THOMA-WORRINGER; SØRENSEN; LOPEZ-FANDIÑO, 2006; ZIMECKI; KRUZEL, 2007; ROYLE; McINSTOSH; CLIFTON, 2008; MADUREIRA et al., 2010). Accordingly, milk whey and GMP have been used as ingredients in foodstuff matrix, as well as flavored beverages, yogurts, meringues, biscuits, and fruit jelly formulations (KELLEHER et al., 2003; ANTUNES; ANTUNES; CARDELLO, 2004; MARTIN-

Received 8/9/2009

Accepted 9/7/2010 (004326)

Unidad de Investigación Ciencia y Tecnología de los Alimentos, Facultad de Ciencias Veterinarias, Universidad del Zulia, Maracaibo, Edo, Zulia, Venezuela,

e-mail:evelin.rojas@fcv.luz.edu.ve

${ }^{*}$ Corresponding author 
DIANA; PELAEZ; REQUENA, 2004; MARTIN-DIANA; FRÍAS; FONTECHA, 2005; KYUNGWHA et al., 2007; LIM et al., 2007; SAND-STRÖM et al., 2008; CRUZ et al., 2009; TRANJAN et al., 2009; ZOELLNER et al., 2009; EVANS et al., 2010; MacLEOD et al., 2010).

Several methodologies have been used to detect and study the structure and properties of GMP (LIESKE; KONRAD, 1996; NAKANO; OZIMEK, 2000b; DE SOUSA et al., 2000; MIRALLES et al., 2001; BENITEZ; PONCE; NOA 2001; ROSSANO; D'ELIA; RICCIO, 2001; WANG; LUCCY, 2003; KIM et al., 2005). However, recently used isolation techniques for GMP production are based on chromatography, electrophoresis, and ultrafltration of caseinate/casein as peptide source (SILVAHERNÁNDEZ et al., 2005; NAKANO; IKAWA; OZIMEK, 2007; SODRE DA SILVA et al., 2007; KREUS; KULOZIK, 2009; SUSIL; BRAD, 2010). Protein source and isolation method are crucial to obtain a high yield purified GMP.

Between 1998 and 2008, milk production worldwide raised 134 million tons (24\%) with a parallel rising in cheese production (approximately 24\%), mostly in Latin America (INTERNATIONAL..., 2009). These data indicate that milk whey is the principal by-product produced by the dairy industry. Its proper disposal without environmental damage has become an increasing problem in some countries, whereas in many other countries it has been considered a good protein source which is used in foodstuff processing. However statistical information about the production and consumption of milk whey protein supplemented foodstuff worldwide is not yet available (INTERNATIONAL..., 2009).

In conclusion, milk whey is an important source of proteins and peptides of high biological value that could be efficiently used, and whey GMP could be utilized in medicinal and functional foodstuff formulations. Therefore, this is a descriptive study that aims to evaluate GMP's isolation and recovery by means of milk whey's thermal treatment and to assess the most appropriate conditions that could allow industrial production.

\section{Materials and methods}

\subsection{Biological material}

Three sources of whey were used in this research and named as follows:

- Sweet whey: fresh milk whey obtained from cheese manufacturing immediately transported to the laboratory cooled at $10^{\circ} \mathrm{C}$;

- Resuspended commercial whey: Whey Protein Natural Source BCAA was resuspended in NaCL isotonic solution to obtain a concentration of $7 \% \mathrm{w} / \mathrm{v}$. It was used as a positive control for GMP presence;

- Acid whey: obtained by fresh whole milk coagulation with $30 \%$ acetic acid. It was used as a negative control for GMP presence.

To eliminate any insoluble material, all whey samples were previously centrifuged at $4{ }^{\circ} \mathrm{C}$ and $5000 \mathrm{~g}$ for 15 minutes using a HETTICH centrifuge model 52R. The pellets were discarded, and the supernatants were reserved.

\subsection{GMP isolation by thermal treatment}

Eighteen isolations were performed by means of thermal precipitation described as follows: GMP was isolated from $2 \mathrm{~L}$ of sweet whey, resuspended commercial whey, and acid whey, which were heated at $90{ }^{\circ} \mathrm{C}$ for 60 minutes and then cooled at room temperature. After cooling, they were centrifuged for 30 minutes at $5000 \mathrm{rpm}$ in an IEC Model K 3/4 HP centrifuge; the pellets were discarded, and the supernatants were used for SDS-PAGE and chemical tests.

\subsection{Protein quantitative analysis}

Total soluble protein quantification of isolated GMP fractions was done using the Bradford method (BRADFORD, 1976). For this purpose, a protein calibration curve was constructed using bovine serum albumin (BSA) as standard at concentrations from 0 to $16 \mu \mathrm{g} / 100 \mu \mathrm{L}$. The samples were analyzed in duplicate by mixing 10 and $20 \mu \mathrm{L}$ of each fraction with 90 and $80 \mu \mathrm{L}$ of distilled water respectively, and $2 \mathrm{~mL}$ of Bradford reagent. After mixing, absorbances were measured at $595 \mathrm{~nm}$ in a BIO-RAD spectrophotometer, model SMART SPEC 3000. Protein concentration was calculated using protein calibration curve and using the method of least squares with the absorbances obtained for each sample.

\subsection{Sodium Dodecyl Sulfate-Polyacrylamide Gel Electrophoresis (SDS-PAGE)}

GMP isolated fractions from sweet and control whey proteins were analyzed by SDS-PAGE using the Laemmli's discontinuous buffer system (LAEMMLI, 1970). Gels with 4 and $15 \% \mathrm{w} / \mathrm{v}$ acrylamide were prepared for stacking and resolving respectively, according to the Mini Protean III de BIO-RAD electrophoretic chamber instruction manual, 2002.

All samples were diluted $2: 1$ in sample reducing buffer containing: $20 \%$ glycerol; $0.01 \%$ bromophenol blue; $10 \%$ $\beta$-mercaptoethanol; $10 \%$ sodium dodecyl sulphate (SDS) $1 \mathrm{M}$ TRIS/HCl, and $\mathrm{pH}$ 6.8, and they were placed in a water boiling bath for 5 minutes. $10 \mu$ g of protein were applied to each sample/ pocket, and electrophoresis was carried out with $300 \mathrm{~mL}$ of Tris-glycine buffer pH 8.3 (0.01 M TRIS; 0.09 M glycine, 1.0\% SDS in distilled water). A constant voltage of $200 \mathrm{v}$ was used with resulting oscillating current of 16-41 $\mathrm{mA}$ for between 45-55 minutes.

Staining of gels was performed under constant shaking in a Coomassie Blue R-250 solution 0.2\% w/v in methanol:acetic acid:water (25:10:65), for 6-12 hours at room temperature. A Methanol:acetic acid:water solution (25:10:65) was used for distaining. The gels were stored in methanol:acetic acid:water (5:10:85).

The molecular masses of all separated fractions were calculated generating a standard curve by plotting molecular weight versus relative mobility (Rf). 


\subsection{Chemical tests characterization}

Qualitative chemical tests were applied to untreated and heated $\left(90^{\circ} \mathrm{C}\right)$ whey proteins according to Robyt and White (1990). Bradford: mixing $50 \mu \mathrm{L}$ of sample and $500 \mu \mathrm{L}$ of Bradford reagent. The development of a blue color indicates a positive test result. Sullivan: mixing $100 \mu \mathrm{L}$ of sample and $100 \mu \mathrm{L}$ of $30 \% \mathrm{w} / \mathrm{v} \mathrm{NaOH}$; heating for 5 minutes at $100{ }^{\circ} \mathrm{C}$, and $50 \mu \mathrm{L}$ of $10 \%$ lead acetate was added. Development of a dark black-brown color indicates the presence of Sulfur. Xantoproteic: $100 \mu \mathrm{L}$ of sample and $100 \mu \mathrm{L}$ of concentrated $\mathrm{HNO}_{3}$ were mixed and heated for 5 minutes at $100{ }^{\circ} \mathrm{C}$. The development of a yellow color indicates a positive test result. Lowry: $100 \mu \mathrm{L}$ of sample and $500 \mu \mathrm{L}$ of Lowry reagent $(2 \%$ $\mathrm{Na}_{2} \mathrm{CO}_{3}, 0.1 \mathrm{M} \mathrm{NaOH}, 1 \% \mathrm{CuSO}_{4} \cdot 5 \mathrm{H}_{2} \mathrm{O}, 2 \%$ sodium-potassium tartrate) were mixed, and 10 minutes later $100 \mu \mathrm{L}$ of a solution of Fenol Folin-Ciocalteu's reagent:distilated water (1:2) were added. The development of blue color indicates a positive result. Molibdate-Vanadate: $100 \mu \mathrm{L}$ of sample and $1 \mathrm{~mL}$ of molibdatevanadate reagent ( $5 \%$ ammonium molibdate: $0.25 \%$ ammonium vanadate $1: 1)$ were mixed. Yellow color indicates a positive result. $\mathrm{H}_{2} \mathrm{PO}_{4}$ was included as a positive control. Benedict: $5 \mathrm{~mL}$ of Benedict reagent (prepared by mixing $17.3 \mathrm{~g}$ sodium citrate, $10 \mathrm{~g}$ sodium carbonate, $1.73 \mathrm{~g}$ copper sulfate in $100 \mathrm{~mL}$ distilled water) were added and heated for 5 minutes at $100^{\circ} \mathrm{C}$ to 8 drops of all whey protein and supernatants heated at $90^{\circ} \mathrm{C}$. The samples were cooled at room temperature. Development of a red colored precipitate of $\mathrm{Cu}_{2} \mathrm{O}$ indicates a positive result for the presence of reducing sugars.

The presence or absence of some chemical groups in GMP was determined with those tests. Water was included as a negative control in all chemical tests; BSA and $\kappa$-casein were included as positive controls.

\subsection{Isoelectric point determination}

For the determination of the isoelectric point, a $17 \mathrm{~mL}$ aliquot of sweet whey was used, which was centrifuged for 5 minutes at $7000 \mathrm{rpm}$ and $4{ }^{\circ} \mathrm{C}$ in order to eliminate insoluble material (initial $\mathrm{pH}=6.58$ ). Volumes of $0.1 \mathrm{~N} \mathrm{CH}_{3} \mathrm{COOH}$ were added to drop the $\mathrm{pH}$ every 0.2 units to the value of 3.60 (ROBYT; WHITE, 1990). Between each $\mathrm{pH}$ variation, whey protein was centrifuged under the prior conditions, and each obtained pellet was resuspended in TRIS/HCl $1.5 \mathrm{M}$ pH 8.8 buffer. Protein determination using SDS-PAGE was performed for all samples.

\subsection{Recovery calculation}

GMP recovery was calculated as the ratio of the total protein in whey and the protein present in each fraction, (Equation 1):

$\%$ Recovery $=\frac{\text { Fraction protein } \mathrm{mg}}{\text { Total protein } \mathrm{mg}} \times 100$

\section{Results and discussion}

\subsection{GMP isolation by means of thermal treatment}

GMP was isolated from all samples tested. Protein content in sweet, resuspended, and acid whey was $8.84 \pm 4.69 \mathrm{~g}$,
$39.93 \pm 11.07 \mathrm{~g}$ and $7.34 \pm 3.06 \mathrm{~g}$, respectively (Table 1 ). Results in sweet whey are lower compared with the data reported by Muñi et al. (2005), who analyzed $20 \mathrm{~L}$ of sweet fresh milk whey and obtained a protein concentration of $0.83 \pm 1.46 \% \mathrm{w} / \mathrm{w}$ (corresponding ca.16.6 g).

Table 1 shows that commercial whey presented higher protein levels compared with the other types of whey. It also shows that acid whey had the lower protein concentration due to acetic acid treatment at $\mathrm{pH} 4.6$, at which the precipitation of casein takes place and leads to insolubilization of protein present in milk clot.

\subsection{SDS-PAGE of thermally treated supernatants}

An aliquot of each whey and its supernatant was analyzed by SDS-PAGE for protein separation and molecular mass determination of each fraction.

In lane 5 in Figure 1, corresponding to sweet whey supernatant, three principal bands of 14,20 , and $41 \mathrm{kDa}$ molecular mass can be observed, which probably correspond to aggregated forms of GMP.

Table 1. Total protein and recovery percentages of milk whey supernatants treated at $90^{\circ} \mathrm{C}$.

\begin{tabular}{lcccc}
\hline \multirow{2}{*}{ Fraction } & $\begin{array}{c}\text { Volume }^{1} \\
(\mathrm{~mL})\end{array}$ & $\begin{array}{c}\text { Proteins }^{1} \\
(\mathrm{mg} / \mathrm{mL})\end{array}$ & \multicolumn{2}{c}{ Total protein } \\
\cline { 4 - 5 } & 2000 & $3.70 \pm 1.50$ & $7.34 \pm 3.06$ & 100 \\
\hline Acid whey & & & $(\mathrm{g})^{1}$ & $\%$ \\
Supernatant $90^{\circ} \mathrm{C}$ & $1530 \pm 70$ & $0.82 \pm 0.23$ & $1.26 \pm 0.41$ & 17.23 \\
& & & & \\
Commercial whey & 2000 & $19.97 \pm 5.50$ & $39.93 \pm 11.07$ & 100 \\
Supernatant $90^{\circ} \mathrm{C}$ & $1430 \pm 180$ & $13.50 \pm 3.20$ & $18.73 \pm 2.15$ & 46.90 \\
& & & & \\
Sweet whey & 2.000 & $5.22 \pm 1.16$ & $8.84 \pm 4.69$ & 100 \\
Supernatant $90{ }^{\circ} \mathrm{C}$ & $1.712 \pm 17.89$ & $1.79 \pm 0.96$ & $3.01 \pm 1.65$ & 34.08 \\
\hline
\end{tabular}

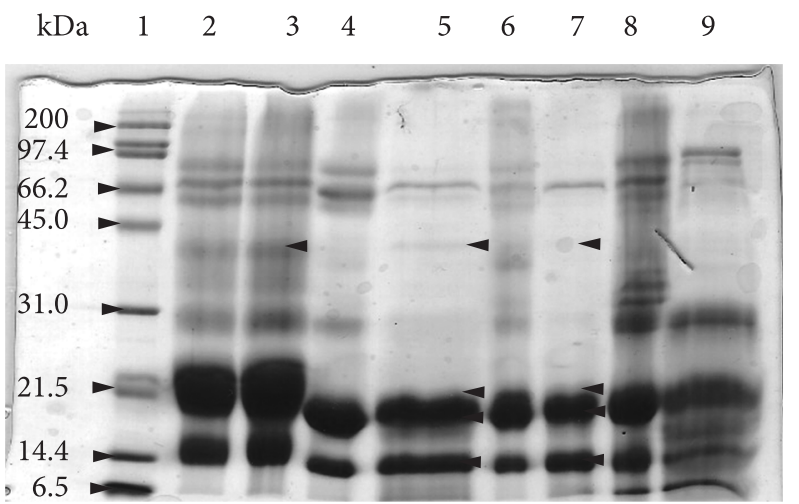

Figure 1. SDS-PAGE of sweet, commercial and acid whey and their supernatants obtained by heating at $90{ }^{\circ} \mathrm{C}$. In pockets can be observed 1: BIORAD Wide range standard; 2: Commercial whey $(10 \mu \mathrm{g})$; 3: Commercial whey supernatant $(10 \mu \mathrm{g})$; 4 : Sweet whey $(10 \mu \mathrm{g})$; 5: Sweet whey supernatant $(10 \mu \mathrm{g}) 6$ : Concentrated sweet whey; 7: Concentrated sweet whey supernatant $(10 \mu \mathrm{g}) ; 8$ : Acid whey $(10 \mu \mathrm{g})$; 9: Acid whey supernatant $(10 \mu \mathrm{g})$. 
The presence of a $20 \mathrm{kDa}$ band may correspond to that obtained by Galindo, Valbuena and Rojas (2006), who performed TCA precipitation of sweet whey and milk-whey mixtures to standardize an SDS-PAGE technique for GMP detection as an adulterant in fresh milk. In this study, GMP was visualized as a $20.9 \mathrm{kDa}$ band, probably corresponding to the trimeric form of the peptide.

Molecular masses of 20 and $41 \mathrm{kDa}$ observed in SDS-PAGE are in agreement with those reported by Kawasaki et al. (1993), who found an apparent molecular mass between $20-50 \mathrm{kDa}$ at $\mathrm{pH} 7$ for aggregated forms of GMP from sweet whey, analyzed by means of HPLC. The $41 \mathrm{kDa}$ band, which is observed in lower intensity, probably corresponds to the hexameric form of GMP since it cannot be observed in the negative control (lane 9 but is present in the positive control (lane 3). The two major components of milk whey are $\beta$ lactoglobulin and $\alpha$ lactoalbumin with molecular masses of 18.3 and $14.2 \mathrm{kDa}$, respectively, both proteins go under thermal denaturation at $90{ }^{\circ} \mathrm{C}$ or more; however, some genetic varieties are thermostable at this temperature (WITHNEY, 1988). This probably explains the presence of two bands with similar molecular masses for these proteins in acid whey.

Finally, the hypothesis that the $20 \mathrm{kDa}$ band observed in $90{ }^{\circ} \mathrm{C}$ treated supernatants corresponds to residual $\kappa$-casein $(19 \mathrm{kDa})$ can be discarded because although this molecule is thermostable, it becomes part of the clot formed during enzymatic or acid treatment of milk during cheese manufacturing. Heat $\left(85-90^{\circ} \mathrm{C}\right)$ also induces the association of $\beta$-lactoglobulins with $\kappa$-casein micells by disulfide bonds and hydrophobic interactions, which leads to precipitation (WALTRA; JENNES, 1987).

\subsection{Chemical tests in thermally treated whey protein and supernatants}

In order to detect the presence of several chemical groups in the GMP structure in qualitatively, some tests were performed in whey proteins and their supernatants. Table 2 presents the results of each test for all samples analyzed showing that all chemical tests were positive for all whey proteins and their $90{ }^{\circ} \mathrm{C}$ treated supernatants. However, the results for sweet and acid whey supernatants were less positive in comparison with untreated whey proteins.

Bradford test's results for all supernatants indicate peptide and/or protein presence. This finding is in accordance with the amount of protein present in them (Table 1), and protein bands present in SDS-PAGE with molecular masses are similar to those reported by other authors (GALINDO; VALBUENA; ROJAS, 2006; KAWASAKI et al., 1993; WITHNEY, 1988) for aggregated forms of GMP.

Furthermore, the Benedict test (which detects reducing sugars) results were positive for all supernatants, with higher intensity in acid whey. These results suggest GMP presence in all supernatants since it contains reducing sugars such as galactosamine in its peptide structure. The results obtained for acid whey were as expected since this whey protein does not contain GMP but contains other whey proteins such as a-lactoalbumin, A and $\mathrm{M}$ inmunoglobulins, which could contain reducing sugars in their structure.

A positive result on the Sullivan and Xantoproteic tests (which detect sulphide groups and aromatic ring, respectively) in these supernatants indicate that partially pure isolation of GMP can be achieved by thermal treatment at $90^{\circ} \mathrm{C}$ since this peptide does not contain sulfur or aromatic amino acids. Is possible that some residues of amino acids, peptides, or proteins from milk whey remain in $90^{\circ} \mathrm{C}$ treated supernatant.

Table 2. Chemical tests applied to whey supernatants treated at $90^{\circ} \mathrm{C}$.

\begin{tabular}{|c|c|c|c|c|c|c|}
\hline \multicolumn{2}{|c|}{ Types of whey } & Sullivan & Xantoproteic & Bradford & Molibdate /vanadate & Benedict \\
\hline \multicolumn{2}{|c|}{ Acid whey } & +++ & ++ & ++ & +++ & N/A \\
\hline \multicolumn{2}{|c|}{ Supernatant $90^{\circ} \mathrm{C}$} & ++ & + & + & ++ & +++ \\
\hline \multicolumn{2}{|c|}{ Commercial whey } & + & ++ & +++ & + & $\mathrm{N} / \mathrm{A}$ \\
\hline \multicolumn{2}{|c|}{ Supernatant $90^{\circ} \mathrm{C}$} & + & ++ & ++ & + & + \\
\hline \multicolumn{2}{|c|}{ Sweet whey } & ++ & ++ & + & +++ & N/A \\
\hline \multicolumn{2}{|c|}{ Supernatant $90^{\circ} \mathrm{C}$} & + & + & + & ++ & ++ \\
\hline \multirow[t]{7}{*}{ controls } & $\mathrm{KH}_{2} \mathrm{PO}_{4}$ & $\mathrm{~N} / \mathrm{A}$ & $\mathrm{N} / \mathrm{A}$ & $\mathrm{N} / \mathrm{A}$ & ++++ & $\mathrm{N} / \mathrm{A}$ \\
\hline & $\mathrm{H}_{2} \mathrm{O}$ & - & - & - & - & - \\
\hline & BSA & + & + & + & - & N/A \\
\hline & $\mathrm{k}$-casein & + & + & + & + & $\mathrm{N} / \mathrm{A}$ \\
\hline & Lactose & $\mathrm{N} / \mathrm{A}$ & $\mathrm{N} / \mathrm{A}$ & N/A & $\mathrm{N} / \mathrm{A}$ & ++ \\
\hline & Galactose & N/A & N/A & N/A & $\mathrm{N} / \mathrm{A}$ & ++ \\
\hline & Glucose & $\mathrm{N} / \mathrm{A}$ & N/A & $\mathrm{N} / \mathrm{A}$ & $\mathrm{N} / \mathrm{A}$ & ++ \\
\hline
\end{tabular}

+ Weak positive; ++ Midle positive; +++ Intense positive; ++++ Very intense positive; N/A Not applied. 
Other researchers have obtained GMP preparations with traces of aromatic amino acids, Nakano and Ozimek (2000a) applied three different methods (Sephacryl S-200 gel chromatography in sodium acetate $\mathrm{pH} 7.0$ and 3.5, treatment with cetylpyridinium chloride, and Sephacryl S-200 chromatography followed by Sephadex G-75 in dissociating conditions and deproteinization with TCA followed by gel chromatography) and obtained high purity GMP preparations, which contained traces of phenylalanine ( $<1$ residue by peptide). Similarly, a higher purity product formulated and manufactured as a dietary supplement by Davisco Foods International Inc., (2007), known as Glycomacropeptide Bioactive Whey Protein reports a 0.5 and $0.1 \mathrm{~g} / 100 \mathrm{~g}$ of phenylalanine and tyrosine, respectively.

\subsection{GMP isoelectric point}

Figure 2 shows SDS-PAGE of $\mathrm{pH}$ values which presented precipitation. It can be observed that all analyzed pellets present several protein bands with different molecular masses. The two lowest bands (14 and $21 \mathrm{kDa}$ ) are those of higher percentage, which indicates that these are the more efficient $\mathrm{pH}$ values for the acid precipitation of these proteins. When bands present at $\mathrm{pH} 3.6$ (lane 7) are compared with the rest of $\mathrm{pH}$ values, it is possible to observe only in this lane two main bands with molecular masses are 14 and $20 \mathrm{kDa}$; these are similar to the ones observed in SDS-PAGE of sweet whey supernatant, heated at $90{ }^{\circ} \mathrm{C}$, showing that those bands probably correspond to the dimeric and trimeric forms of GMP since Tomczak, Lazzari and Bibleski (2007) reported a GMP isoelectric point close to $\mathrm{pH} 3.8$.

\subsection{GMP recovery}

As a result of heating whey at $90{ }^{\circ} \mathrm{C}$, two fractions of $34.08 \%$ and $46.9 \%$ of protein were obtained; the former from acid and latter from resuspended commercial whey (Table 1).

The recovery percentages obtained correspond to those reported by Li and Mine (2004). These authors compared the GMP chromatographic profile from cheese manufacturing whey using three different methods: trichloracetic acid (TCA)

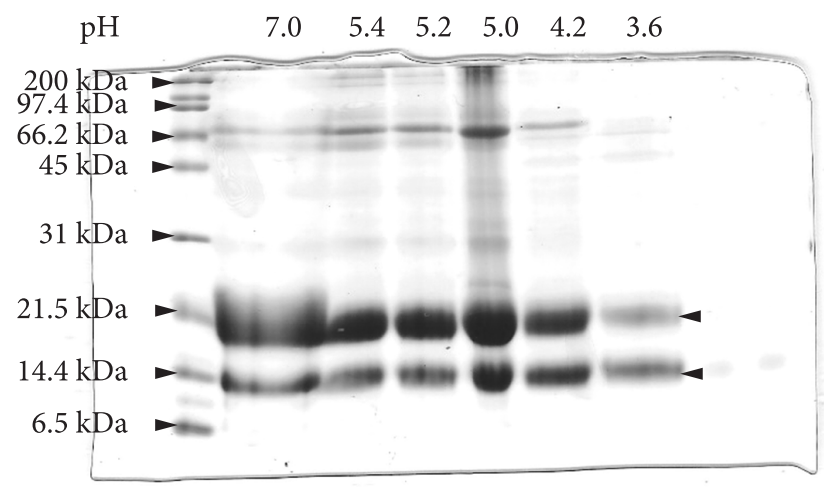

Figure 2. SDS - PAGE of pellets obtained in isoelectric point determination. In pockets can be observed: 1 : BIORAD wide range standard, 2: Sweet whey supernatant at $90{ }^{\circ} \mathrm{C}$; 3-7: pellets obtained at $\mathrm{pH} 5.4,5.2,5.0,4.2,3.6$ respectively. treatment, ethanol precipitation, and ultrafiltration. The results showed that highest GMP recovery (33.9\%) was achieved by ultrafiltration, which became the most convenient way to eliminate pretreatments with TCA and ethanol. Our findings are in agreement with the results reported by Oliva, Escobar and Ponce (2002), who reported that GMP is present in cheese manufacturing whey in concentrations from $1.2-1.5 \mathrm{~g} / \mathrm{L}$, which accounts for between $10-25 \%$ of whey protein.

A $17 \%$ protein recovery in acid whey (which does not contain GMP) shows that with this procedure, peptides and proteins different from GMP remain in solution, which explains why real recovery of this peptide could be around $17 \%$ and $29 \%$ from sweet and resuspended commercial whey, respectively. These results are in accordance with those obtained for supernatants of acid whey treated at $90{ }^{\circ} \mathrm{C}$ in the chemical tests and SDS-PAGE.

All results show a partial isolation and purification of GMP from sweet milk whey. This suggests that a high scale, low cost enriched preparation of GMP that could indeed be used as an ingredient for foodstuff supplementation or as an alternative source of high quality amino acids for patients with phenylcetonuria. However, further research must be conducted to quantify physiologically active concentrations of GMP, and their impact in foodstuff final structure; research on digestibility and dose response analysis should be conducted in order to use this preparation in foodstuff formulations.

\section{Conclusions}

Milk whey's thermal treatment at $90^{\circ} \mathrm{C}$ allowed obtaining GMP preparations. However, no characteristic chemical groups were found in the peptides structure in such preparations showing that a partially purified preparation was obtained.

Under the isolation and separation conditions used in this study, the peptide exhibits good aggregation, which explains why a dimeric enriched preparation of GMP was obtained.

GMP's recovery from sweet milk whey was significant $(34.08 \%)$, which makes its use and production in an industrial scale possible.

By means of thermal treatment of sweet milk whey, it is possible to obtain GMP preparations that could be used as a potential source of essential amino acids by incorporating them as a supplement in several foodstuff.

A proposed recommendation for further research is the design of biological and/or nutritional assays with the GMP preparations obtained.

\section{References}

ABD EL-SALAM, M.; EL-SHIBINI, S.; BUCHHEIM, W. Characteristics and potential uses of the casein macropeptide. International Dairy Journal, v. 6, p. 327-341, 1996. http://dx.doi.org/10.1016/09586946(95)00026-7

ANTUNES, A. E. C.; ANTUNES, A. J.; CARDELlO, H. M. A. B. Chemical, physical, microstructural and sensory properties of set fat-free yogurts stabilized with whey protein concentrate. Milchwissenschat, v. 59, n. 3-4, p. 161-165, 2004. 
BARÓ, L. et al. Péptidos y proteínas de la leche con propiedades funcionales. Ars Pharmaceutica, v. 42, n. 3-4, p. 135-145, 2001.

BENITEZ, E.; PONCE, P.; NOA, M. Detection of rennet whey in powder milk by gel filtration high performance liquid chromatography (GFC-HPLC). Revista de Salud Animal, v. 23, n. 1, p. 27-31, 2001.

BRADFORD, M. A rapid and sensitive method for the quantization of microgram quantities of protein utilizing the principle of proteindye binding. Analytical Biochemistry, v. 72, p. 248-254, 1976. http://dx.doi.org/10.1016/0003-2697(76)90527-3

BRODY, E. Biological activities of bovine glycomacropeptide. British Journal of Nutrition, v. 80, n. S39-S46, 2000. Supplement 1.

CHOW, D.; HARPER, W. Selected characteristics of casein glycomacropeptide from different sources. Milchwissenschaft, v. 56, n. 7 , p. $370-373,2001$.

CRUZ, A. et al. Milk drink using whey butter cheese (queijo manteiga) and acerola juice as a potential source of vitamin C. Food and Bioprocess Technology, v. 2, p. 368-373, 2009. http://dx.doi. org/10.1007/s11947-008-0059-9

DAVISCO FOODS INTERNATIONAL INC. Bio-Pure GMP ${ }^{\mathrm{TM}}$. Version 07J-1001. Disponível em: <http://www.daviscofoods.com/ fractions/gmp.cfm.htm>. Acesso em: 9 set. 2007.

DE SOUSA, E. et al. Electrophoforetic analysis to detect and quantify additional whey in milk and dairy beverages. Ciência e Tecnologia de Alimentos, v. 20, n. 3, p. 314-317, 2000. http://dx.doi. org/10.1590/S0101-20612000000300007

DOULTANI, S.; TURHAN, K.; ETZEL, M. Whey protein isolate and glycomacropeptide recovery from whey using ion exchange chromatography. Journal of Food Science, v. 68, n. 4, p. 13891395, 2003. http://dx.doi.org/10.1111/j.1365-2621.2003.tb09655.x

EVANS, J. et al. Comparison of composition and sensory properties of $80 \%$ whey protein and milk serum protein concentrates. Journal of Dairy Science, v. 93, n. 5, p. 1824-1843, 2010. PMid:20412896. http://dx.doi.org/10.3168/jds.2009-2723

ETZEL, M. R Manufacture and use of dairy protein fractions. Journal of Nutrition, v. 134, p. 996S-1002S, 2004. PMid:15051860.

GALINDO, L.; VALBUENA, E.; ROJAS, E. Estandarización de la detección del glicomacropéptido por PAGE-SDS como índice de adulteración de leche. Revista Científica FCV-LUZ, v. 16, n. 3, p. 308-314, 2006.

INTERNATIONAL DAIRY FEDERATION. The Wordl Dairy Situation 2009. Bulletin of the International Dairy Federation, v. $438,2009$.

KAWASAKI, Y. et al. Inhibition by k-casein glycomacropeptide and lactoferrin of influenza virus hemagglutination. Bioscience, Biotechnology and Biochemistry, v. 57, p. 1214-1215, 1993. PMid:7763995. http://dx.doi.org/10.1271/bbb.57.1214

KELLEHER, S. L. et al. Glycomacropeptide and a-lactalbumin supplementation of infant formula effects growth and nutritional status in infants rhesus monkeys. American Journal of clinical Nutrition, v. 77, p. 1261-1268, 2003. PMid:12716681

KIM, Y. et al. Purification and characterization of human caseinomacropeptide produced by a recombinant Saccharomyces cerevisiae. Protein Expression and Purification, v. 41, n. 2, p. 441-446, 2005. PMid:15866733. http://dx.doi.org/10.1016/j. pep.2005.02.021

KREUS, M.; KULOZIK, U. Separation of glycoylated caseinomacropèptide at pilot scale using membrane adsorption in direct-capture mode. Journal of Chromatography A, v. 1216, n. 50, p. 8771-8777, 2009. PMid:19215932. http://dx.doi.org/10.1016/j. chroma.2009.01.084
KYUNGWHA, L. et al. Acceptable low-phenylalanine foods and beverages can be made with glycomacropeptide from cheese whey for individuals with PKU. Molecular genetics and metabolism, v. 92, p. 176-178, 2007. http://dx.doi.org/10.1016/j. ymgme.2007.06.004

LAEMMLI, U. Cleavage of structural proteins during the assembly of the head of bacteriophage $T_{4}$. Nature, v. 227, n. 15, p. 580-685, 1970.

LI, E.; MINE, Y. Comparison of chromatography profile of glycomacropeptide from cheese whey isolated using different methods. Journal of Dairy Science, v. 87, n. 1, p. 174-177, 2004. http://dx.doi.org/10.3168/jds.S0022-0302(04)73155-0

LIESKE, B.; KONRAD, D. A new method to estimate caseinomacropeptide and glycomacropeptide from trichloroacetic acid filtrates. Milchwissenschaft, v. 51, n. 8, p. 431-435, 1996.

LIM, K. et al. Acceptable low phenylalanine foods and beverages can be made with glicomacropéptido from cheese whey for individuals with PKU. Molecular Genetics and Metabolism, v. 2, n. 1-2, p. 176-178, 2007. PMid:17644019. PMCid:2032016. http://dx.doi. org/10.1016/j.ymgme.2007.06.004

MacLEOD, E. et al. breakfast with glycomacropeptide compared with amino acids suppresses plasma grelin levels in individuals with phenylketonuria. Molecular Genetics and Metabolism, v. 100, n. 4, p. 303-308, 2010. http://dx.doi.org/10.1016/j.ymgme.2010.04.003

MADUREIRA, A. et al. Physiological properties of bioactive peptides obtained from whey proteins. Journal of Dairy Science, v. 93, n. 2, p. 437-455, 2010. PMid:20105516. http://dx.doi.org/10.3168/ jds.2009-2566

MARSHALL, K. Therapeutic applications of whey protein. Alternative Medicine Review, v. 9, n. 2, p. 136-144, 2004.

MARSHALL, S. Casein macropeptide from whey a new product opportunity. Food Research, v. 51, n. 1-2, p. 86-91, 1991.

MARTIN-DIANA, A. B.; FRÍAS, J.; FONTECHA, J. Emulsifying properties of whey protein concentrate and caseinomacropeptide of cow, ewe and goat. Milchwissenschaft, v. 60, p. 363-367, 2005.

MARTIN-DIANA, A. B.; PELAEZ, C.; REQUENA, T. Rheological and structural properties of fermented goat's milk supplemented with caseinomacropeptide and whey protein concentrate. Milchwissenschaft, v. 59, p. 383-386, 2004.

MIRALLES, B. et al. Improved method for simultaneous determination of whey protein, caseins, and para $\kappa$-casein in milk and dairy products by capillary electrophoresis. Journal of Chromatography, v. 915, p. 225-230, 2001. http://dx.doi.org/10.1016/S00219673(01)00617-3

MUÑI, A. et al. Eficiencia de un sistema de ultrafiltración/ nanofiltración tangencial en serie para el fraccionamiento y concentración del lactosuero. Revista Científica FCV-LUZ, v. 15, n. 4, p. 361-367, 2005.

NAKANO, T.; IKAWA, N.; OZIMEK, L. Detection of sialylated phosphorylaled kappa-casein glycomacropeptide electrophoresed on polyacrylamide gels and cellulose acetate strips by the thiobarbituric acid and malachite green dye reactions. Journal of Agricultural and Food Chemistry, v. 55, n. 7, p. 2714-2726, 2007. http://dx.doi.org/10.1021/jf062987f

NAKANO, T.; OZIMEK, L. Purification of Glycomacropeptide from Caseinate Hydrolysate by Gel Chromatography and Treatment with Acidic Solution. Journal of Food Science, v. 65, n. 4, p. 588590, 2000a. http://dx.doi.org/10.1111/j.1365-2621.2000.tb16054.x

NAKANO, T.; OZIMEK, L. Purification of glycomacropeptide from no dializable fraction of sweet whey by anion-exchange 
chromatography. Biotechnology Techniques, v. 13, n. 11, p. 739742, 2000b. http://dx.doi.org/10.1023/A:1008957928446

OLIVA, Y.; ESCOBAR, A.; PONCE, P. Caseinomacropéptido bovino: una alternativa para la salud. Revista de Salud Animal, v. 24, n. 2 , p. 73-81, 2002.

ROBYT, J.; WHITE, B. Biochemical techniques: Theory and practice. Waveland Press, 1990.

ROSSANO, R.; D’ELIA, A.; RICCIO, P. One step separation from lactose: Recovery and purification of major cheese whey protein by hydroxyapatite: A flexible procedure suitable for small- and medium-scale preparations. Protein Expression and Purification, v. 21, p. 165-169, 2001. http://dx.doi.org/10.1006/prep.2000.1350

ROYLE, P.; McINSTOSH, G.; CLIFTON, P. Whey protein isolate and glycomacropeptide decrease weight gain an alter body composition in male Wistar rats. British Journal of Nutrition, v. 6, p. 1-6, 2008.

SAND-STRÖM, O. et al. of alpha-lactalbumin-enriched formula containing different concentrations of glycomacropeptide on infant nutrition. American Journal of Clinical Nutrition, v. 87, n. 4, p. 921-928, 2008.

SILVA-HERNÁNDEZ, E. et al. Aislamiento y caracterización del glicomacropéptido (GMP) y suero libre de GMP y sus usos potenciales como nutracéuticos. In: CONGRESO IBEROAMERICANO DE INGENIERÍA DE ALIMENTOS, 5., 2005, Puerto Vallarta, México. Anais... Puerto Vallarta, 2005. Tomo 2. 81, p. 1-5.

SUSIL, F.; BRAD, W. Quantitation of N-acetylneuraminic (sialic) acid in bovine glycomacropeptide (GMP). Journal of Food Composition and Analysis, v. 23, n. 4, p. 359-366, 2010. http:// dx.doi.org/10.1016/j.jfca.2009.12.004
TRANJAN, B. et al. Development of goat cheese whey-flavoured beverages. International Journal of Dairy Technology, v. 62, p.438443, 2009. http://dx.doi.org/10.1111/j.1471-0307.2009.00491.x

SODRE DA SILVA, C. et al. Partitioning of caseinomacropeptide in aqueous two-phase systems. Journal of Chromatography B, v. 858, p. 205-210, 2007. PMid:17869592. http://dx.doi.org/10.1016/j. jchromb.2007.08.033

THOMA-WORRINGER, C.; SØRENSEN, J.; LOPEZ-FANDIÑO, R. Health effects and technological features of caseinomacropeptide. International Dairy Journal, v. 16, p. 1324-1333, 2006. http:// dx.doi.org/10.1016/j.idairyj.2006.06.012

TOMCZAK, L.; LAZZARI, E.; BIBLESKI, I. Isolation and purification of milk whey glycomacropeptide. Boletim CEPPA, v. 25, n. 1, p. 121-132, 2007.

WALTRA, P.; JENNES, R. Química y física lactológica. Zaragoza: Edit. Acribia S.A., 1987.

WANG, J.; LUCCY, J. Use of multi-angle angle laser light scattering and size-exclusion chromatography to characterize the molecular weight and types of aggregates present in commercial whey protein products. Journal of Dairy Science, v. 86, n. 10, p. 3090-3101, 2003.

WITHNEY, R. Proteins in milk. In: WONG, N. P. et al. (Eds.). Fundamentals of Dairy Chemistry. New York: Van Nostrand Reinhold, 1988.

ZIMECKI, M.; KRUZEL, M. Milk-derived proteins and peptides of potential therapeutic and nutritive value. Journal of Experimental Therapeutics and Oncology, v. 6, n. 2, p. 89-106, 2007. PMid:17407968

ZOELLNER, S. et al. Whey beverage with acai pulp as food carrier of probiotic bacteria. Australian Journal of Dairy Technology, v. 64, p. $165-169,2009$. 